\title{
TINDAK TUTUR SISWA DALAM PEMBELAJARAN ONLINE VIA WHATSAPP DI KELAS 3 SD NEGERI 2 SETROJENAR (Studi Deskriptif dilihat dari Lokusi, Ilokusi, dan Perlokusi)
}

\author{
Fani Saputri, Aninditya Sri Nugraheni \\ Program Studi Pendidikan Guru Madrasah Ibtidaiyah \\ Fakultas Ilmu Tarbiyah dan Keguruan \\ UIN Sunan Kalijaga Yogyakarta \\ fanisptr198@gmail.com
}

\begin{abstract}
ABSTRAK: Penelitian ini memiliki tujuan guna memaparkan dan mendeskripsikan mulai dari jenis tindak tutur, bentuk, dan maksud tuturan siswa yang dipakai ketika pembelajaran online via WhatsApp di kelas 3 SDN 2 Setrojenar. Penelitian dilakukan dengan studi deskriptif yang dilihat berdasarkan jenis tindak tutur lokusi, ilokusi, dan perlokusi. Adapun jenis dari penelitian yang digunakan dalam penyusunan artikel ini yaitu berupa penelitian deskriptif kualitatif. Sumber data yang diperlukan dalam penelitian yaitu sumber dalam bentuk tertulis yang ada pada pembelajaran online via WhatsApp di kelas 3 SDN 2 Setrojenar. Data dari penelitian yang dilakukan yaitu berupa keseluruhan tuturan yang berjenis lokusi, ilokusi, dan perlokusi. Teknik yang digunakan dalam pengumpulan data yakni teknik baca, simak, dan catat. Analisis data pada penelitian ini yaitu berupa analisis data kualitatif. Peneliti mendapatkan hasil penelitian yang dilakukan berdasarkan tindak tutur siswa saat pembelajaran online via WhatsApp bahwa di dalam pembelajaran tersebut terdapat, jenis-jenis tindak tutur yaitu tindak tutur lokusi, tindak tutur ilokusi, dan tindak tutur perlokusi. Berdasarkan jenis tindak tutur lokusi terdapat bentuk informatif dan bentuk pertanyaan. Bentuk asertif, direktif, dan ekspresif juga terdapat pada tindak tutur jenis ilokusi. Sedangkan pada tindak tutur terdapat bentuk dorongan yang membuat mitra tutur melakukan sesuatu. Tindak tutur siswa pada pembelajaran online via whatsApp di kelas 3 SDN 2 Setrojenar memiliki maksud tuturan yakni untuk mempengaruhi, menginformasikan sesuatu, memuji, dan mengapresiasi.

KATA KUNCI: pragmatik; tindak tutur; whatsApp
\end{abstract}

ACTION OF TUTUR STUDENTS IN VIA WHATSAPP ONLINE LEARNING IN CLASS 3 SD NEGERI 2 SETROJENAR

(Descriptive Study based on Location, Illocution and Perlocution)

ABSTRACT: This study aims to describe and describe the types of speech acts, forms, and intentions of students' speech used in online learning via WhatsApp in grade 3 of SDN 2 Setrojenar. The study was conducted with a descriptive study that was seen based on the type of speech acts of locution, illocution, and perlocution. The type of research used in the preparation of this article is descriptive qualitative research. Sources of data needed in the study are sources in written form that exist in online learning via WhatsApp in grade 3 SDN 2 Setrojenar. Data from the research carried out in the form of a whole speech that is of type locution, illocution, and perlocution. The techniques used in data collection are reading, listening, and note-taking. Data analysis in this research is in the form of qualitative data analysis. Researchers get the results of research conducted based on students' speech acts when learning online via WhatsApp that in learning there are, the types of speech acts are locus speech acts, illocutionary speech acts, and perlocutionary speech acts. Based on the type of locus speech act there are informative forms and forms of questions. The assertive, directive, and expressive forms also occur in speech acts of the illocutionary type. Whereas in speech act there is a form of encouragement that makes the speech partner do something. The students' speech acts on online learning via WhatsApp in grade 3 SDN 2 Setrojenar have the purpose of speech which is to influence, inform something, praise, and appreciate.

KEYWORDS: pragmatics; speech act; WhatsApp.

\begin{tabular}{llll}
\hline Diterima: & Direvisi: & Distujui: & Dipublikasi: \\
$13-07-2020$ & - & $03-10-2020$ & $28-10-2020$
\end{tabular}

Pustaka : Saputri, F \& Nugraheni A. S. (2020). Tindak Tutur Siswa Dalam Pembelajaran Online Via Whatsapp di Kelas 3 Sd Negeri 2 Setrojenar (Studi Deskriptif dilihat dari Lokusi, Ilokusi, dan Perlokusi). Fon : Jurnal Pendidikan Bahasa dan Sastra Indonesia, 16(2), 89-96. 


\section{PENDAHULUAN}

Pada hakikatnya dalam interaksi antar manusia bahasa mempunyai peranan yang sangat penting. Bahasa merupakan susunan bunyi yang dipakai untuk berkomunikasi oleh masyarakat sosial. Hal ini guna mempermudah suatu kelompok sosial di dalam bermasyarakat. Dengan komunikasi yang jelas dapat tersampaikan dan dimengerti oleh kedua belah pihak yang bersangkutan, sehingga tujuan dari berkomunikasi tercapai. Dalam berkomunikasi tentunya menggunakan serangkaian tindak tutur untuk mencapai maksud dan tujuan tertentu. Tindak tutur tidak terjadi begitu saja, tetapi memiliki peran, arti, dan arah, serta dapat mempengaruhi mitra tutur untuk melakukan sesuatu, (Luthfiyanti, 2017). Keragaman bahasa timbul karena kegunaan dari pemakaian bahasa itu sendiri. Setiap ragam bahasa menyimpan sistem yang berbeda, (vita, 2015). Dengan struktur yang berbeda dapat menjadi sebuah ciri masing-masing dari bahasa tersebut. Tindak tutur ialah suatu kajian tentang pragmatik yang menggunakan bahasa berdasarkan pada konteksnya. Pragmatik yaitu bagian dari ilmu bahasa yang membahas tentang tuturan yang merupakan kemauan dari penutur itu sendiri dan berdasarkan pada konteksnya, (Susmiatun, 2016). Konteks di sini memiliki arti yakni latar belakang yang sama- sama diketahui oleh pembicara dan lawan bicaranya yang masing-masing berada pada tempat yang menampung sebuah perihal tuturan itu berlangsung. Perihal tuturan yakni kejadian yang melibatkan beberapa kelompok yang saling bertindak tutur dalam suatu keadaan dan lokasi tertentu yang sama. Jenis tindak tutur terbagi menjadi 3 yaitu tindak tutur lokusi (location), ilokusi (illocation), dan perlokusi (perlocution). Tindak tutur lokusi yaitu tindak tutur yang digunakan untuk menyatakan hal tertentu. Sedangkan, tindak tutur jenis ilokusi merupakan tindak tutur yang memiliki tujuan tertentu. Tindak tutur selanjutnya yaitu tindak tutur jenis perlokusi, yaitu tuturan yang dapat mempengaruhi pendengarnya atau pembaca yang selanjutnya mereka akan melakukan dari akibat tindak tutur tersebut.

Dalam pembelajaran di sekolah tentunya terdapat peristiwa tindak tutur. Komunikasi yang terjadi dalam pembelajaran online via WhatsApp yang dilakukan siswa dengan guru ataupun kedua siswa atau lebih yang saling bertindak tutur merupakan suatu hal yang menarik untuk diteliti. Tuturan yang terjadi tentu memiliki tindak tutur yang beragam jenisnya. Peneliti di dalam penelitian berusaha meneliti yang hanya fokus pada tindak tutur siswa yang kita lihat berdasarkan jenis-jenis tindak tutur seperti di atas yakni, tindak tutur lokusi (location), tindak tutur ilokusi (illocation), dan tindak tutur perlokusi (perlocution).

Ketertarikan peneliti melakukan penelitian pada aspek tindak tutur dengan judul "Tindak tutur siswa dalam pembelajaran online via whatsApp di kelas 3 SDN 2 Setrojenar", karena penelitian- penelitian sebelumnya yang menggunakan objek dari Aplikasi canggih yaitu WhatsApp masih jarang dilakukan. Meskipun sangat banyak penelitian terdahulu yang kajiannya tindak tutur, peneliti bertujuan untuk menyajikan hasil akhir penelitian ini dengan berusaha menyajikan pebelitian yang berbeda. Seperti penelitian yang dilakukan terdahulu oleh Ida Hamidah Universitas Kuningan dengan mengankat judul penelitiannya yaitu "tindak tutur guru bahasa indonesia dalam kegiatan belajar mengajar di SMK Negeri Se-Kabupaten Kuningan." Hasil dari penelitian ini yaitu memaparkan bahwa guru bahasa 
Indonesia SMK Se-Kabupaten Kuningan memakai jenis tindak tutur berupa tindak tutur lokusi (locution), ilokusi (illocution), dan perlokusi (perlocution). Hal yang membuat berbeda antara penelitian ini dengan penelitian yang dilakukan Ida Hamidah yaitu, pada penelitian itu hanya meneliti tindak tutur dengan subjek guru dan hanya fokus pada tuturan guru tersebut. Dengan hal tersebut, peneliti menginginkan hal yag berbeda dan lebih lanjut mengenai tindak tutur dengan subjek penelitian siswa dalam suatu pembelajaran yang dilakukan secara Online via WhatsApp.

Tuturan itu dapat diungkapkan menggunakan lisan ataupun dengan bentuk tulisan (Tarigan, 2015). Suatu tuturan pasti terdapat penuturnya, adapaun penutur yang mengungkapkan tuturan menggunakan lisan yakni pembicara, sedangkan mitra tuturnya yaitu lawan bicaranya (pendengar). Sedangkan tuturan yang menggunakan bentuk tulisan dalam penyampaian, maka penuturnya ialah penulis dari apa yang ditulisnya, dan pembaca sebagai mitra tuturnya. Dari hal tersebut menyatakan bahwa kajian pragmatik itu meliputi bahasa tulis yang kedua pihak saling mengetahui konteks dalam pembicaraan yang sedang dilakukan. Tidak hanya bahasa lisan tetapi juga bahasa tulis juga mengandung unsur pragmatik di dalamnya. Media apapun yang digunakan dapat terjadi pula tindak tutur jika di dalamnya mengandung penggunaan bahasa. Seperti halnya pembelajaran online via WhatsApp di kelas 3 SDN 2 Setrojenar pun dapat terjadi tindak tutur karena terdapat unsurunsur tindak tutur seperti pihak penutur dan mitra tutur (guru dan siswa) serta pesan dalam bentuk tertulis sebagai tuturannya. Komunikasi yang terjadi di WhatsApp saat pembelajaran juga harus ada unsur kesantunan dalam menulis, hal ini kesantunan dalam proses belajar mengajar dapat membuat tuturan yang sedang dilakukan dapat dimengerti dengan jelas oleh pihak- pihak yang bersangkutan. selain itu, juga melatih kesantunan siswa yang harus di ajarkan sejak dini, (Heny, Cahyo, 2019).

WhatsApp Messenger yaitu sebuah aplikasi yang memiliki sistem pesan untuk smartphone. Aplikasi ini dapat digunakan untuk mengirim pesan seperti SMS tetapi berbeda dalam hal biaya. Pada SMS biasanya biaya diambil dari pulsa yang dimiliki tetapi jika menggunakan WhatsApp biaya tidak diambil dari pulsa melainkan paket internet. Paket internet biasanya juga digunakan untuk mengakses email, browsing ataupun aplikasi cangging lainnya. Perkembangnya zaman yang semakin modern diikuti pula teknologi yang semakin canggih membuat semua pekerjaan terasa lebih ringan untuk dilakukan. Dengan kemudahan yang ada dapat kita manfaatkan untuk hal-hal positif yang dapat menguntungkan atau menimbulkan hal positif pula.

Semenjak terjadinya wabah virus Covid-19 pemerintah Indonesia mencanangkang sebuah kebijakan yang ditujuakan oleh semua warga Indonesia untuk tetap stay at home dan melakukan Social distancing (pembatasan sosial) guna mencegah penyebaran virus ini. Sebagai upaya dari pemerintah untuk mencegah virus ini, sebagai imbasnya sekolah-sekolah diminta untuk melakukan pembelajaran dari rumah masing -masing dan mematuhi protokol yang ada. Mulai tanggal 16 April 2020 sekolah-sekolah di Indonesia ditutup dan memulai belajar secara daring (online). Pembelajaran online via WhatsApp sebagai salah satu pembelajaran siswa di SDN 2 Setrojenar selama masa sosial distancing ini. Sangat jelas bahwa aplikasi WhatsApp ini sangat mempermudah bagi kita yang sedang berada di dalam keadaan seperti ini. Tanpa harus bertatap muka langsung, memakai seragam, dan duduk rapih di 
bangku kelas, proses pembelajaran tetap berjalan meski tidak seperti biasanya. Meskipun demikian, hal itu tidak boleh mengurangi semangat kita dalam belajar.

Pembelajaran online via WhatsApp tentunya sangat menarik. Siswa dan guru dapat melakukan komunikasi jarak jauh hanya menggunakan aplikasi ini dengan mudah. Di dalam pembelajaran online tentunya terdapat macam-macam tindak tutur antara siswa dengan guru meskipun dalam bentuk tulisan. Hal ini menjadi daya tarik bagi peneliti untuk meneliti lebih lanjut seperti apa tindak tutur yang terdapat dalam proses pembelajaran online via WhatsApp. Penelitian mengenai tindak tutur siswa memiliki pemandangan yang menarik karena tujuan dari penelitian ini akan memberikan sebuah pemamaparan jenis tuturan siswa saat kegiatan pembelajaran online via WhatsApp. Penulis memilih meneliti siswa yang sedang belajar di kelas $3 \mathrm{SD}$ Negeri 2 Setrojenar dengan judul penelitian " Tindak Tutur Siswa dalam Pembelajaran Online Via WhatsApp di Kelas 3 SD N 2 Setrojenar". Dilihat dari permasalahan yang ada di atas, dapat disimpukan latar belakang dari masalahmasalahnya yaitu berikut ini.

1) Apa saja jenis tindak tuturnya siswa pada pembelajaran online via WhatsApp di kelas 3 SD $\quad \mathrm{N} \quad 2$ Setrojenar.

2) Bagaimana bentuk dan wujud tindak tutur yang dipakai siswa di pembelajaran online via WhatsApp pada kelas 3 SD N 2 Setrojenar.

3) Bagaimana maksud tuturan yang ada pada tuturan siswa ketika proses pembelajaran online via whatsApp di kelas 3 SD N 2 Setrojenar.

Adapun tujuan penelitian yang dilakukan peneliti berdasarkan simpulan permasalahan-permasalahan tersebut di atas yakni sebagai berikut.

1) Ingin lebih tahu apa saja jenis-jenis tindak tutur yang siswa lakukan ketika pembelajaran online via WhatsApp di kelas 3 SD N 2 Setrojenar.

2) Ingin lebih tahu bentuk dari tindak tutur yang siswa pakai dalam pembelajaran online via WhatsApp di kelas 3 SD N 2 Setrojenar.

3) Ingin mengetahui maksud tuturan siswa untuk apa ketika pembelajaran online via whatsApp di kelas 3 SDN 2 Setrojenar.

\section{METODE PENELITIAN}

Penelitian dari sebuah artikel ini menggunakan penelitian jenis deskriptif kualitatif. Adapun maksudnya yaitu untuk mendeskripsikan fakta yang menjadi sasaran penelitian. Pada metode deskriptif ini merupakan penelitian yang menemukan fakta-fakta apa adanya, (Mustofa, 2010). Hal ini berarti di dalam penulisan artikel, berusaha memaparkan secara runtut semua fakta kebahasaan yang terjadi ketika pembelajaran online via WhatsApp di kelas 3 SDN 2 Setrojenar. Objek penelitian ini adalah seluruh siswa kelas 3 SDN 2 Setrojenar yang menggunakan bahasa tulis dalam tuturannya. Pendeskripsian tindak tutur dalam pembelajaran online via WhatsApp di kelas 3 SDN 2 setrojenar merupakan tujuan awal dari penelitian. Sumber data yang dipakai yakni sumber berbentuk tertulis (pesan tertulis) yang terdapat dalam pembelajaran online via WhatsApp sejak 27 April 2020 sampai pada tanggak 16 Mei 2020. Data dari penelitian ini adalah seluruh tidak tutur yang berbentuk pesan tertulis di pembelajaran online. Peneliti menggunakan cara simak sebagai metode penelitian. Adapun teknik untuk memdapatkan sebuah data yakni memakai, teknik baca, teknik menyimak, dan catat.

\section{HASIL DAN PEMBAHASAN}

Berikut ini adalah Hasil dari Penelitian yang didapat oleh peneliti saat melakukan penelitian di SDN 2 Setrojenar 
tahun ajaran 2020/2021 saat kegiatan belajar mengajar menggunakan grup WhatsApp kelas 3. Penelitian mendapatkan data diperoleh melalui teknik catat, dokumentasi, dan simak yang dilakukan mulai tanggal 27 April 2019 sampai 16 Mei 2020 di SDN 2 Setrojenar. Setelah peneliti menganalisis data didapatkan hal seperti berikut, yakni peneliti mendeskripsikan jenis, bentuk, dan maksud dari tintak tutur saat pembelajaran berlangsung.

Tabel 1. Jenis-jenis tindak tutur

\begin{tabular}{|c|l|c|}
\hline No. & \multicolumn{1}{|c|}{$\begin{array}{c}\text { Jenis } \\
\text { Tindak Tutur }\end{array}$} & Jumlah \\
\hline 1 & Lokusi & 27 \\
\hline 2 & Ilokusi & 88 \\
\hline 3 & Perlokusi & 5 \\
\hline
\end{tabular}

\section{Tindak Tutur Lokusi}

Berikut ini komunikasi yang terjadi secara online via whatsApp di grup kelas 3. Pada kali ini, penelitian fokus pada tuturan yang dilontarkan oleh siswa kelas 3 SDN 2 Setrojenar yang mana sebagai sasaran penelitian. Contoh tuturan tindak tutur lokusi sebagai berikut.

Data 1.

Siswa : "Alhamdulillah tugas tema 7, halaman 59 - 112, sudah selesai dan sudah dikumpulkan tadi pagi”.

Tuturan tersebut dituturkan oleh seorang siswa dengan tujuan memberikan pernyataan saja, tanpa keinginan mitra tutur berbuat sesuatu. Informasi yang diberikan oleh siswa tersebut yaitu mengenai tugas tema 7, bahwasannya dirinya telah menyelesaikan dan mengumpulkan tugas tersebut yang diberikan oleh gurunya.

Data 2.

Siswa : "Aku mengerjakan tugas habis sahur baru selesai teman-teman".
Tuturan tersebut dituturkan hanya untuk memberikan informasi saja tentang dirinya selesai mengerjakan tugas ketika habis sahur. Tuturan tersebut dilakukan tanpa maksud lain kecuali hanya untuk memberikan informasi saja dan pada tuturan ini, penutur tidak mengaharap akan reaksi atau tindakan dari mitra tutur terhadap tuturannya tersebut.

\section{Data 3.}

Siswa: "teman-teman, ada yang belum mengumpulkan tema 6 tidak yah?".

Guru: "Yang tema 6 sudah semua. Yang belum tema 7 perkembangan teknologi”.

Tuturan di atas berbentuk pertanyaan, bahwa seorang siswa bertanya siapa yang belum mengumpulkan tugas tema 6. Dilihat dari tuturannya, siswa tersebut tidak mempunyai maksud lain kecuali hanya bertanya apa yang ada pada tuturan.

Berdasarkan kesimpulan dari penelitian (Wahyu Wibowo, 2015), jika si subjek penyaji wacana berniat menuturkan sesuatu, yang Oleh karena itu tidak ada keharusan baginya untuk melakukannya berarti niatnya itu tindak tutur lokusi. Berbeda menurut Nadar (dalam Juleha, 2017), tindak lokusi adalah tindak tutur yang tidak terlalu penting pada bagian ini, dan tujuannya hanya sebagai pernyataan saja.

Tindak tutur lokusi bisa dilakukan tanpa harus ada konteksnya, dan jenis ini cenderung mudah dikenali, Wijana dan Rohmadi (dalam Juleha, 2017, hlm.14). Oleh karena itu, berdasarkan pendapatpendapat para pakar di atas dapat kita tarik kesimpulannya yaitu tuturan yang bertujuan memberikan informasi semata ialah jenis lokusi. Sehingga tuturan jenis tersebut tak akan menyebabkan mitra tutut terpengaruh untuk melakukan sesuatu. 
Tabel 2. Persentase tindak tutur lokusi

\begin{tabular}{|l|c|c|}
\hline \multirow{2}{*}{} & \multicolumn{2}{|c|}{ Bentuk Tindak Tutur } \\
\cline { 2 - 3 } & Pertanyaan & Pernyataan \\
\hline Lokusi & $25 \%$ & $75 \%$ \\
\hline
\end{tabular}

Berdasarkan tabel diatas, tindak tutur yang digunakan oleh siswa kelas 3 SDN 2 Setrojenar pada aplikasi WhatsApp menunjukkan bahwa bentuk tindak tutur dari jenis lokusi yang sering digunakan yaitu tuturan dalam bentuk pernyataan. Berdasarkan presentase sebanyak $75 \%$, bentuk pernyataan di sini hanya bermaksud untuk memberikan informasi tanpa harus mitra tutur melakukan sesuatu.

\section{Tindak Tutur Ilokusi}

Di bawah ini terdapat contoh tuturan jenis ilokusi yang dilakukan oleh siswa kelas 3 SDN 2 Setrojenar. Contoh tuturan tindak tutur lokusi berikut ini.

\section{Data 1.}

Siswa 1 : "Gambarnya bagus sekali lulu"

Siswa 2: "Comprang-campreng dit, karena gak jadi- jadi tadi."

Tuturan itu diucapkan dalam bentuk tulisan mengandung makna tertentu sebagai contoh dari jenis ilokusi. Siswa 1 mengatakan bahwa gambarnya siswa 2 bagus sekali. Tuturan tersebut merupakan tuturan memuji. Jadi, kesimpulannya, contoh yang dipaparkan itu ialah jenis ilokusi bertipe ekspresif dengan wujud yaitu memuji si mitra tutur (siswa 2). Tindak tutur bertipe ekspresif terdiri dari ucapan terima kasih, ucapan selamat, menyanjung, memuji, serta mengkritik, (Apriastuti, 2017). Fungsi tindak tutur dengan tipe ekspresif yang sering digunakan oleh siswa kelas 3 SDN 2 Setrojenar saat pembelajaran berlangsung yaitu tuturan memuji, dan mengucapkan terimakasih.

\section{Data 2.}

Guru memberikan sebuah tugas kepada siswa-siswinya dalam bentuk microsoft word. Kemudian salah satu dari mereka menanggapinya.

Siswa : "Maaf bu guru, kalau bisa share tugasnya jangan memakai program microsoft, karena tidak semua hp bisa membukanya".

Guru : "Iya maaf bu guru kemarin lupa ngasih tugasnya pake microsoft word. Bu guru sadar setelah Ande tanya tentang tugas."

Tuturan itu adalah salah satu contoh dari tindak tutur jenis ilokusi. Terdapat informasi bahwa Siswa menyarankan gurunya dengan saran supaya tugas yang dishare tidak memakai program microsoft dikarenakan tidak semua $\mathrm{hp}$ mendukung aplikasi tersebut untuk membukanya. Penutur mengekspresikan tindak tutur menyarankan dengan tuturan kalau bisa share tugasnya jangan memakai program microsoft, karena tidak semua hp bisa membukanya. Pada tuturan itu berarti tindak tutur yang digunakan bertipe direktif dengan wujud tuturan menyarankan. Tujuan yang dimaksudkan yaitu agar guru mau melakukan tindakan dari hasil tuturan siswanya. Tindak tutur direktif biasanya terdiri tuturan suruh, permohonan, menuntut, bentuk saran, dan penentang.

\section{Data 3.}

Guru memberikan tugas untuk dikerjakan hari itu.

$$
\begin{array}{ll}
\text { Siswa } & \text { : "Sudah selesai, bu”. } \\
\text { Guru } & : \text { "Alahamdulillah, } \\
& \text { terimakasih mba Anis". }
\end{array}
$$

Tuturan di atas kali ini menunjukkan tindak tutur ilokusi yang bertipe asertif. Maksud dari penutur (siswa) yaitu 
memberitahukan mitra tutur (guru) bahwa dirinya telah menyelesaikan tugasnya. Selain itu, pada tuturan sudah selesa, bu tidak hanya sekedar memberitahu saja akan tetapi, mengandung arti lain, yaitu penutur (siswa) menginginkan mitra tutur (guru) untuk memeriksa tugasnya yang telah selesai dikerjakan. Jadi pada tuturan tersebut mengandung tindak tutur ilokusi dengan tipe asertif dalam wujud memberitahu. Fungsi tindak tutur asertif adalah menyampaikan kebenaran proposisi dalam bentuk berspekulasi, menyatakan, menyebutkan, menuntut, (Apriastuti, 2017). Bentuk tindak tutur tipe asertif ini, sering dilakukan siswa ketika siswa sudah selesai akan tugasnya. Setelah itu siswa akan memberitahu gurunya bahwa tugasnya sudah selesai, seperti tuturan di atas. Selain itu juga sebagai laporan kepada gurunya agar segera dikoreksi tugasnya.

Tabel 3. Persentase bentuk tindak tutur Ilokusi

\begin{tabular}{|c|c|c|c|c||}
\hline No & Jenis & \multicolumn{3}{|c|}{ Bentuk Tindak Tutur } \\
\cline { 2 - 5 } & $\begin{array}{c}\text { tindak } \\
\text { tutur }\end{array}$ & Asertif & Ekspresif & Direktif \\
\hline & Lokusi & $60 \%$ & $30 \%$ & $10 \%$ \\
\hline
\end{tabular}

Berdasarkan tabel di atas, terlihat jelas bahwa penggunaan tuturan bentuk asertif yang paling banyak dipakai saat pembelajaran. Jika dalam presentase tindak titur bentuk asertif sebanyak $60 \%$.

Bentuk tuturan ilokusi yang dilakukan oleh siswa kelas 3 SDN 2 Setrojenar kepada guru ataupun sesama siswa berbentuk tuturan ekspresif, direkrif, dan asertif. Bentuk ketiga tuturan tersebut yang paling banyak digunakan selama pembelajaran berlangsung yaitu tindak tutur dengan tipe asertif dan dalam wujud tuturan memberitahu mitra tutur atau lawan bicaranya.

Berdasarkan penelitian yang dilakukan oleh (Sari, 2015) tuturan ilokusi tidak hanya bertujuan untuk menyatakan sesuatu saja, tetapi juga untuk melakukan sesuatu bagi mitra tuturnya. Dengan hal itu, berarrti tindak tutur lokusi selalu ada dalam peristiwa tuturan baik itu lisan maupun tulisan.

\section{Tindak tutur Perlokusi}

Saat pembelajaran berlangsung di kelas 3 SDN 2 Setrojenar, tentu ada tindak tutur jenis perlokusi. Berikut ini contohnya.

Siswa 1 (lulu) membagikan foto dirinya sedang mengerjakan tugas menggambar.

Siswa 2 : "Semangat mengerjakannya mba lulu."

Siswa 1 : "Oke “.

Tuturan tersebut merupakan contoh dari tindak tutur perlokusi karena dapat memberi efek atau pengaruh terhadap mitra tutur. Di dalam tuturan itu, penutur (siswa 2) memberikan semangat kepada mitra tutur (siswa 1) dalam mengerjakan tugasnya. Efek dari tuturan tersebut diharapkan agar si mitra tutur merasa bersemangat dalam mengerjakan tugasnya.

Tindak tutur perlokusi yaitu tuturan yang diucapkan oleh penutur kepada mitra tutur yang memiliki efek atau pengaruh, (Susmita, 2019). Efek dari tuturan ini berupa tindakan yang penuh perhatian, berpartisipasi, dan aktif dalam pembelajaran, (Sari, 2015).

\section{KESIMPULAN}

Menurut pembahasan yang telah dipaparkan diperoleh hasil bahwa jenis tindak tutur yang digunakan oleh siswa kelas 3 di SDN 2 Setrojenar saat pembelajaran via online WhatsApp ialah lokusi, ilokusi, dan perlokusi. Pada ketiga jenis ini ternyata tindak tutur yang paling sering dilontarkan yaitu jenis tindak tutur ilokusi sebanyak 88 tuturan. Sedangkan, sisanya yaitu lokusi sebanyak 27 tuturan, 
dan perlokusi hanya sebanyak 5 tuturan. Berdasarkan hal tersebut tuturan yang digunakan oleh siswa kelas 3 yaitu kebanyakan tuturan dengan tujuan memberikan informasi dan maksud lain kepada mitra tutur(lawan bicaranya).

Bentuk tindak tutur dari jenis- jenis tindak tutur di atas sangatlah beragam. Mulai dari jenis tindak tutur lokusi, di sini siswa lebih sering menggunakan bentuk pernyataan untuk memberikan informasi saja dan tanpa mempengaruhi lawan bicara untuk melakukan sesuatu. Pada bagian jenis tindak tutur ilokusi, siswa menggunakan tiga tipe bentuk tuturan yaitu asertif, direktif, dan ekspresif. Dari ketiga tipe itu, tuturan asertif berada pada posisi pertama yang berarti sering digunakan saat pembelajaran berlangsung. Asertif di sini bertujuan memberikan informasi atau memberitahu dan memiliki maksud lain yg dapat berpengaruh pada mitra tutur untuk bertindak suatu hal.

Wujud dari bentuk tindak tutur di atas juga bermacam- macam mulai dari tuturan yang hanya sekedar memberitahu, tuturan memuji, menyarankan, sampai tuturan yang dapat memberikan efek langsung kepada mitra tutur untuk melakukan sesuatu.

\section{DAFTAR PUSTAKA}

Apriastuti, N. (2017). Bentuk, Fungsi dan Jenis Tindak Tutur dalam Komunikasi Siswa di Kelas IX Unggulan SMP PGRI 3 Denpasar. Jurnal Imiah Pendidikan Dan Pembelajaran. 1(1). 38-47.

Heny \& Cahyo. (2019). Bentuk Lokusi, Ilokusi, dan Perlokusi Siswa dalam Pembelajaran Tematik. Jurnal Bahastra. 39 (2). $86-91$.
Juleha. (2017). Tindak Tutur Siswa Dalam Pembelajaran Bahasa Indonesia Kelas X SMK Negeri 4 Bandar Lampung Tahun Ajaran 2016/2017. Bandar Lampung : Universitas Lampung.

Luthfiyanti, Lita. (2017). Jenis dan Fungsi Tindak Tutur Guru dan Siswa dalam Proses Belajar-mengajar di TKIT Ukhuwah Banjarmasin (the Type and Function of Speech Acts Teachers and Students in Teaching and learning in TKIT ukhuwah banjarmasin.Jurnal Bahasa, Sastra Dan Pembelajarannya (Jbsp).

Mustofa Djaelani. (2010), Metode Penelitian Bagi Pendidik. Jakarta: PT. Multi Kreasi Satudelapan

Nirmala, V. (2015). Tindak Tutur Ilokusi Pada Iklan Komersial Sumatera Ekspres. Kandai, 11(2), 139-150.

Sari, N. (2015). Kajian Lokusi, Ilokusi, dan Perlokusi dalam Wacana Kelas Akselerasi SMPN I Kota Bengkulu. Diksa,1(1), 18-25.

Susmiatun. (2016), Tindak Tutur Direktif Guru dan Siswa dalam Pembelajaran di Kelas III SDN TIPO Palu. e-jurnal Bahasantodea 4 (1).

Susmita, N. (2019). Tindak Tutur Guru dan Siswa dalam Pembelajaran Bahasa Indonesia. iiCET, 4(1), 2530.

Tarigan, H. G. (2015). Berbicara Sebagai Suatu Keterampilan Berbahasa. Bandung: Angkasa.

Wibowo, Wahyu. (2015). Konsep Tindak Tutur Komunikasi. Jakarta: PT Bumi

Aksara. 